\title{
Autosomal recessive spastic ataxia of Charlevoix-Saguenay
}

\begin{abstract}
Figure 1 Atrophy of the vermis, mainly of the upper part on a T2-weigthed image $(A$, arrow), and linear hypointensities in the pons on fluidattenuated inversion recovery image ( $B$, arrow)
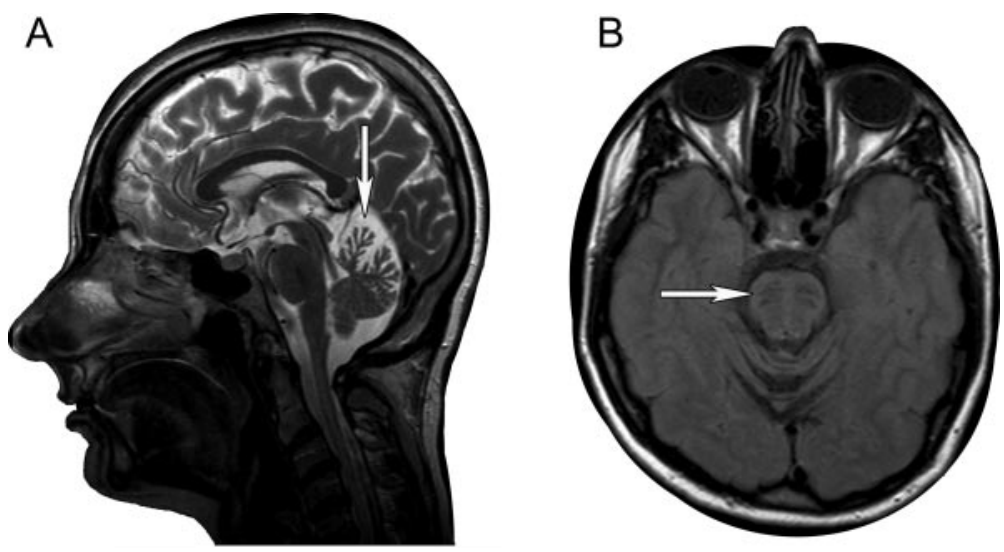

A 40-year-old woman with delayed motor milestones and high arches since childhood was investigated for a progressive gait disorder from the age of 24 years. On clinical examination, a spastic and ataxic gait was present, with mild ataxia in upper limbs, dysarthria, and nystagmus. Nerve conduction study/EMG revealed a demyelinating neuropathy. MRI of the brain (figure 1) and fundus photography (figure 2) suggested autosomal recessive spastic ataxia of Charlevoix-Saguenay (ARSACS) ${ }^{1}$ and the diagnosis was genetically confirmed. ${ }^{2}$ The combination of spinocerebellar ataxia with demyelinating neuropathy, superior vermis atrophy, and pontine linear hypointensities should prompt the diagnosis of ARSACS, which may be an underdiagnosed condition outside Quebec.
\end{abstract}

Figure 2 Color (A) and black and white (B) picture of fundus revealing hypermyelinated fibers in the retina, which are present in some cases of autosomal recessive spastic ataxia of Charlevoix-Saguenay

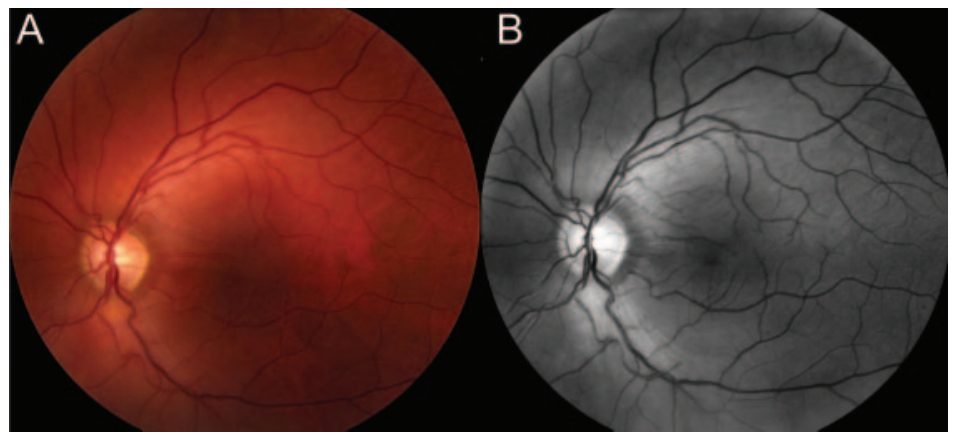

Philip Van Damme, MD, PhD, Philippe Demaerel, MD, PhD, Werner Spileers, MD, PhD, Wim Robberecht, MD, PhD, Leuven, Belgium

Disclosure: The authors report no disclosures.

Address correspondence and reprint requests to Dr. Philip Van Damme, Neurology Department, U.Z. Leuven, Herestraat 49, 3000 Leuven, Belgium; philip.vandamme@uz.kuleuven.be

1. Martin MH, Bouchard JP, Sylvain M, St-Onge O, Truchon S. Autosomal recessive spastic ataxia of Charlevoix-Saguenay: a report of MR imaging in 5 patients. AJNR Am J Neuroradiol 2007;28:1606-1608.

2. Engert JC, Berube P, Mercier J, et al. ARSACS, a spastic ataxia common in northeastern Quebec, is caused by mutations in a new gene encoding an 11.5-kb ORF. Nat Genet 2000;24:120-125. 


\section{Neurology}

\section{Autosomal recessive spastic ataxia of Charlevoix-Saguenay \\ Philip Van Damme, Philippe Demaerel, Werner Spileers, et al. \\ Neurology 2009;72;1790}

DOI 10.1212/WNL.0b013e3181a60a9a

This information is current as of May 18, 2009

\section{Updated Information \& Services}

References

Citations

Subspecialty Collections

Permissions \& Licensing

Reprints including high resolution figures, can be found at: http://n.neurology.org/content/72/20/1790.full

This article cites 2 articles, 0 of which you can access for free at: http://n.neurology.org/content/72/20/1790.full\#ref-list-1

This article has been cited by 1 HighWire-hosted articles: http://n.neurology.org/content/72/20/1790.full\#\#otherarticles

This article, along with others on similar topics, appears in the following collection(s):

MRI

http://n.neurology.org/cgi/collection/mri

Peripheral neuropathy

http://n.neurology.org/cgi/collection/peripheral_neuropathy Spinocerebellar ataxia

http://n.neurology.org/cgi/collection/spinocerebellar_ataxia

Information about reproducing this article in parts (figures,tables) or in its entirety can be found online at:

http://www.neurology.org/about/about_the_journal\#permissions

Information about ordering reprints can be found online:

http://n.neurology.org/subscribers/advertise

Neurology ${ }^{\circledR}$ is the official journal of the American Academy of Neurology. Published continuously since 1951, it is now a weekly with 48 issues per year. Copyright . All rights reserved. Print ISSN: 0028-3878. Online ISSN: 1526-632X.

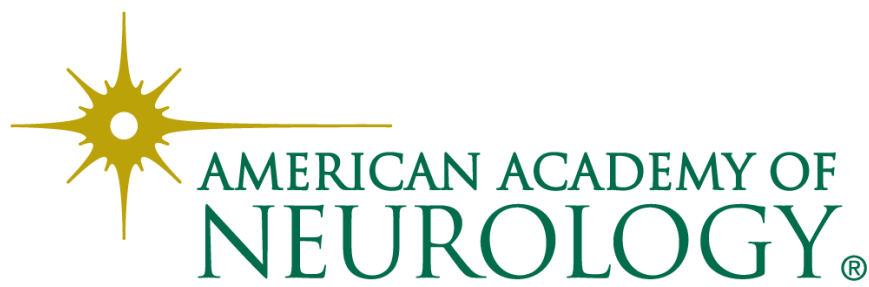

